\title{
Another way of "amusing ourselves to death"? Experience, ideological fantasy, and labor control in variety entertainment production
}

Wenjuan Jia* and Kaiou Zhong

* Correspondence: gm03jwj@126. com

School of Sociology and Political Science, Shanghai University, Shanghai, China

\begin{abstract}
Compared with traditional industries, new changes have taken place in the labor process and manufacturing consent in cultural and creative industries. In entertainment labor, managers transform high-intensity labor into pleasant entertainment through relational work, emotional work, and sentimental work. In contrast to traditional industries, labor control in entertainment does not rely on organizational institutions or economic incentives but is based on supplemental cultural factors, such as relationships, emotion, and sentiment. At the same time, the logic of ideological operation behind manufacturing the consent of laborers is no longer according to the traditional Marxist-Althusserian interpretation in which managers shape a particular idea through the control of the labor process while concealing the real labor-capital relation with a false consciousness. It becomes a case of a Lacanian-Zizekist description: the laborer enters a realistic fantasy through specific experience and pursues his plus-de-jouir in ideological reality. In the end, the laborers devote their body and soul to work.
\end{abstract}

Keywords: Cultural and creative industries, Labor process, Entertainment labor, Relational work, Ideological fantasy

Had Irving Berlin changed one word in the title of his celebrated song, he would have been as prophetic, albeit more terse, as Aldous Huxley. He need only have written, There's No Business But Show Business.

-Neil Postman: Amusing ourselves to death 


\section{Introduction: another metaphor for amusing ourselves to death?}

With the brilliant stage lights and deafening music rendering, $\mathrm{I}^{1}$ entered a state of dizziness-- this scene is exactly like the gorgeous, wonderful, and illusive draft stage in the "15 million merits" story of "Black Mirror." Everyone applauds and laughs tirelessly ... This is an ordinary Thursday night recording scene of a variety show. From experience, this recording will end at about 1 am tomorrow --- at this time, entertainers and audiences can go home to sleep, but I have to edit the recorded videos overnight. In order to finish the production of this episode on Friday afternoon, I need to work 30 hours continuously so as to win a laugh from you who will be slouching in a Ge You-esque style in front of the TV that night. Of course, this is just the weekly routine work of an intern in the team of $\mathrm{W}$ director in the Shanghai TV program production company C during a three-month internship. (Field Notes, August 2015)

Neil Postman observed that we had entered an era of "amusing ourselves to death" in which the logic of power domination is entirely different from that in the metaphor of "Animal Farm" and the autocratic thought control declared by George Orwell. In contrast, this domination is pleasant, and people become dependent on entertainment, sinking into sensuality. After that, awakened people degenerate into passive audiences, and cultural life becomes a cycle of entertainment.

Before Postman was worried about popular culture, Antonio Gramsci, in Mussolini's prison, had been shocked by the existence of cultural hegemony, a kind of dominance over ideas, in capitalist countries. He noted that the so-called ideology is neither a cold utopia nor a learned theory but is the creation of a specific fantasy (Gramsci 2000: 290292). Subsequently, Louis Pierre Althusser explained the ideology and its operating logic in more depth. He argued that ideology is a system of representation, a cultural object to be perceived, accepted, or endured. People, unconscious of ideology, acquire their "experience" relationship with the world and acquire this particular kind of unconsciousness called "consciousness" (Althusser 2006: 230). Ideology makes domination invisible precisely because it represents the life experience itself, what Gramsci calls "common sense" (Gramsci 2000: 290-292). Namely, understanding science does not change the way that chopsticks look bent when they're inserted into the water and that the sun looks like it is going around the earth (Burawoy 2008: 39).

Moreover, how can life experience and common sense be false to all sentient beings? When ideology is rooted in the behavior that facilitates its emergence, it can better express and guide the behavior-as Pascal, quoted by Althusser, said: "Kneel down, move your lips in prayer, and you will believe" (Althusser 1971: 168). This is a pessimistic dialectic. Ideology seems to be as unbreakable and mutually reinforcing as the life experience itself, making the existing system stronger. Postman's "amusing ourselves to death" embodies precisely this kind of ideological practice. Just as in the reflection and critique of Theodor Wiesengrund Adorno, since Western capitalism entered a new era, standardized daily life has been mass produced by the cultural industry, and the masses obtain false happiness while consuming, experiencing, and delighting; at the same time, their ability to think and their will to resist are dispelled (Horkheimer and Adorno 2006: 107-130).

$\overline{1 " \mathrm{I} " \text { in this and subsequent case }}$ descriptions refers to the second author of this article. 
The first metaphor of "amusing ourselves to death" did not surpass Marx's dichotomy of economic production and superstructure. According to this dichotomy, although people suffer as slaves in the field of production, they enjoy entertainment like lords in the field of life and dissolve their sufferings of labor with the wonderfulness of life. From Althusser to Rancière, from Marcuse to Benjamin, and from Huxley to McLuhan, academia has carried out continuous and sharp criticism on ideology from different perspectives. Among them, the two research paths of "Cultural Criticism-Communication Theory" and "Labor Criticism-Labor Process Theory" are particularly eyecatching. Michel Burawoy's labor process theory adheres to the centrality of production, conducting empirical research and analysis on "manufacturing consent" in labor. He believes that ideology has been blended with the economic foundation, eliminating the possibility of laborers' resistance. Cultural dominance exists not only in social life but also in labor and production. It is rooted in the deep aspirations and subjectivity of laborers, and under the influence of specific political systems, it has become more difficult to detect but is a dominant Leviathan: the "factory regime" (Burawoy 1985).

In subsequent studies, scholars analyzed ideological domination in the labor process in detail from the perspectives of game mechanisms (Burawoy 2008; Zheng et al. 2015), workplace culture (Kunda and Maanen 1999), and gender performance (Leidner 1991). They found that organizational systems, political norms, and social identities constitute the source of dominance. When workers think that fate is in their own hands and work hard under the influence of various management mechanisms, they enter the capital trap. If we treat Karl Mannheim's (2000) differentiation of ideology as a metaphor, then Postman's "amusing ourselves to death" is exactly what Mannheim said of the representation of total ideology in the field of culture. "Amusing ourselves to death" in the entertainment production arises from a unique labor process that is similar to a special ideology to which he refers, except that this special ideology does not originate from the thinking of individual intellectuals but from a unique labor process.

From June 2015 to February 2016, I conducted eight months of fieldwork as a project intern with Director W's team at Shanghai Program Production Company C, involving a total of three project operations. I also conducted semi-structured interviews with eight interns and regular employees. I found that compared with traditional industries, labor in the entertainment industry has changed: on the one hand, in addition to the media audience and consumers of entertainment products, laborers in the production of the program are also involved in entertainment; therefore, singing, performance, laughter, and shouting are normalized, and the production of variety entertainment program becomes an "entertainment labor" that entertains the audience with its own entertainment. On the other hand, this work/labor does not have time or organizational boundaries, and interns are neither paid nor are within the statutory labor relations. Interns, regardless of their physical exertion, engage in high-intensity and unpaid labor in the context of wonderful entertainment experience, producing well-known cultural products. In this article, our questions are the following: How is the laborers' consent formed? What is the logic of the ideological operation? How does it differ from what we used to know in the labor process theory?

Today, when labor transcends the boundaries of the organization, labor relations, production, and reproduction (Mears 2015) and when the "deregulation" of work has taken place (Kücklich 2005), we must re-examine the classical labor process theory 
from two aspects. On the one hand, we must return to its core and give continuous attention to the ideological domination in labor; on the other hand, we must advance the theory itself based on changes in material practice. Only in this way can classical theories continue to thrive in the changing era.

How does ideological domination in labor occur? In a dialogue with industrial sociology, Burawoy piloted a "system-idea" approach to analyze manufacturing "consent". In his book Manufacturing consent, he explained how managers organize "industrial games" strategically so that workers have developed values in which the interests of both employers and employees are aligned. Subsequent researchers have analyzed how managers use the system of ideas related to race, gender, and citizenship to advance managerial control (Thomas 1982; Lee 1995; Leidner 1991; He 2009). However, from the case of the $\mathrm{W}$ team of Company $\mathrm{C}$, we found that managers have opened up a new path based on "culture experience". Labor control relies on cultural factors such as relationships, atmosphere, and sentiments that are auxiliary in traditional industries. The basis of consent is not an ideology but an emotional experience. Along with this, the logic of ideological operation behind "consent" is no longer traditional MarxistAlthusserian, that states domination is based on people's acceptance of false consciousness, a system of ideas and concepts to cover up the truth of exploitation; it becomes Lacanian-Zizekist, that states domination is based on the generation of real fantasy, an ideological reality that directly informs and satisfies people's desire. It was during the entertainment labor/work in the $\mathrm{W}$ team of Company $\mathrm{C}$ that we observed the warning of Postman: while the laborers were experiencing, getting excited, and being joyful, they obtained the happiness they wanted, but they eliminated their capability of thinking and their will to resist.

\section{Entertainment and precarious labor in marketization}

During the 40 years of reform and opening up, the marketization of China's cultural industry has been cautious and prudent. Like what Mary Gallagher points out, China's market reform began carefully from marginal areas and non-core sectors to avoid a head-on confrontation with socialism (Gallagher 2010). In fact, Chinese vigilance against mass entertainment is rooted in the socialist tradition. Under the warning of sugar-coated cannonballs, a variety of entertainment and decadent music is believed to disintegrate the revolutionary will of the masses. It can be said that the importance of ideology and cultural fronts has never been underestimated. However, as now we move towards an affluent society, people's growing spiritual and cultural needs cannot be ignored, and the best way for people to leave American drama and Japanese and Korean variety shows is obviously to create China's own cultural products. Therefore, even though the country is still struggling with the question of what kind of entertainment products to provide to the people, the marketization of the cultural industry is progressing step by step. In 2009, the National Radio and Television Administration issued the "Reform Opinions on the Separation of Production and Broadcasting for Radio and Television Contents" and began to imitate the foreign model of "separation of production and broadcasting" to produce domestic variety shows. Since then, the capital of all parties has quickly poured into the field of variety entertainment production, which has caused the growth of China's TV program production institutions from 2874 in 2007 
to 8563 at the end of 2014 (China Radio and TV Yearbook Editorial Department 2009: 29 2015: 291).

The market environment for Company $\mathrm{C}$ is not friendly. From a global perspective, the cultural and creative industry is a field in which the law of the jungle prevails. The market trend is constantly changing, and mergers and reorganizations between capital never stop. Here, many small and flexible businesses gather around several oligarchs, and they rob each other of their business and face bankruptcy at any time (Peterson and Anand 2002). The situation in China is even more worrisome. Although the state has vigorously promoted the development of the cultural and creative industries, institutional regulations such as copyright protection have yet to be optimized. When the industry is developing rapidly, competition between capital is disorderly and cruel. While projects and business opportunities abound, risks are everywhere. At this time, all parties in the market are careful and do their best for their profit, and the upstream broadcast platform has passed on the risk to the downstream production company without hesitation. Starting in 2012, Company C signed a gambling agreement with TV station $\mathrm{Z}$ for a well-known variety show. Although the program can be broadcast on TV station $\mathrm{Z}$, Company $\mathrm{C}$ bears all the costs and investment risks of program production, and only if the audience ratings exceed a certain ratio is a producer allowed to participate in the profit sharing. Company $\mathrm{C}$ took a big gamble, and the capital logic behind it was obvious: either you win the pot full, or you lose with your pocket empty.

To cope with the uncertainty of the market, most cultural and creative enterprises use unpaid laborers such as freelancers and playborers (Neff et al. 2005; Kückrich 2005), and of course, the interns. Interns are also referred to as "student digital labor", "invisible workers", and "hope workers" (Perlin 2011; Mayer and Horner 2017). The case of Company $\mathrm{C}$ is similar. Its formal employees are limited to approximately 300 . To accomplish disproportionate tasks, the company recruits many project interns. Project interns are different from campus-recruited interns: the latter are mainly fresh graduates and will become formal employees after their internship period; the former are mainly sophomores and juniors, and their working period is limited to the project cycle. In China's current legal framework, internship counts only as a social practice, and interns are not recognized as laborers. They have no affiliation with the internship unit, and their labor is not protected by the Labor Law and Labor Contract Law (Li 2012; Chen 2010). Therefore, enterprises do not pay formal wages and social welfare or social security for the internship, and no formal system for interns has ever been established. The high quality at a low price makes interns a new labor force in the program manufacturing industry, and production companies continuously publish internship recruitment notices on major online platforms. In popular seasons such as winter and summer vacations, when multiple large-scale projects are operating at the same time, the number of interns in Company $\mathrm{C}$ often exceeds 300, even more than the number of its formal employees.

Interns are recruited and managed by a demanding team of directors. It took me two rounds of interviews to enter Director W's team, which was responsible for the promotion of a well-known variety show and cooperated with Tencent Video to launch its online derivative programs. I joined the team with other 19 students who were majors in journalism, radio, and television, as well as film and television production from different universities across the country. All of them were proficient in media production 
skills such as shooting, filming, and editing. Surprisingly, Director W's team had only five formal employees, two of whom were the chief director and executive director, and the other three employees led and directed the interns for specific tasks. Later, I learned from one of the formal employees that the reason that I was able to join the team was that I was able to edit videos and had participated in the production of a health program.

Under the project-based mode, the pressure from the gambling agreement is passed on to the core director team. It is conceivable that this pressure would finally fall on the interns. This variety show produced by the W team covers 12 episodes. The production of each episode was divided into three phases-Lines/scriptwriting, live recording, and motion picture editing - and each phase took approximately one month. After entering the second phase of the project, two episodes were produced at one time to act in concert with the schedule of star participants, which meant that we worked 12 hours a day, 60 hours a week, including continuous 30 hours on Thursday and Friday. However, despite the high intensity of labor at each phase, the happy state of the interns was continuously maintained: they presented their proposals vividly in brainstorming sessions, ran around excitedly in the recording scene with colorful lights, and laughed hard while editing overnight. Finally, through the concerted efforts of everyone, the broadcast effect of this variety show was exceptionally good, and the ratings hit record highs.

In 2015, this show was so popular that its advertising revenue exceeded 2 billion yuan. A 60 -s ad was sold at a high price of 30 million yuan. The online derivative programs produced by the $\mathrm{W}$ team also had an advertising revenue of 20 million yuan. In that year, Company C's operating income exceeded 1.3 billion yuan, its profit exceeded 1.1 billion yuan, and its profit margin was as high as $85 \%{ }^{2}$ However, interns were almost unpaid. With the surplus of project funds from team W, interns could receive a subsidy of 1000 yuan to 2000 yuan, lower than Shanghai minimum wage of 2020 yuan in 2015 . Interns must rely on their parents to sponsor their living expenses to stay and continue working.

Behind the high yield of Company $\mathrm{C}$ is a managerial question, namely, how to make the best use of interns. This question stems from three factors. First, traditional companies normally only require interns to do auxiliary work. IT technology companies pay college students a piece-rate wage, but Company $\mathrm{C}$ needs unpaid labor to remedy the twofold insufficiency in both capital and labor. This presents a higher requirement for internship labor. Second, from the perspective of instrumental rationality, the purpose of most interns is to gain internship experience and to understand the career insider story rather than to dedicate themselves wholeheartedly. In fact, all the interns in the W team had internship experience in media institutions, and some of them had tried to start their own undertakings. From the perspective of postgraduation careers, there were only five interns who would remain in the program production industry, and the postgraduation careers of the other seven interns had nothing to do with media. Third, interns' work motivation is often driven by "volunteer enthusiasm" and lacks stamina. Ross Perlin noted that although interns were often enthusiastic and

\footnotetext{
${ }^{2}$ Source: Sohu.com (http://mt.Sohu.com/20160618/n4501889080.shtl) and iHeima.com (Http://www.iheima. com/top/2014/0730/1445444.shtml).
} 
committed at the beginning of their work, with the disappearance of the volunteer complex and curiosity, they began to slack off because they had no salary (Perlin 2011: 126). ${ }^{3}$

In summary, a question to be answered is why managerial controls take effect when companies do not provide economic incentives or internal labor market promotion opportunities. When labor intensity is literally exhausting, how is heart-managing possible? How can employment control be achieved when neither labor contracts nor verbal agreements are available? We find that neither pure instrumental rationality nor short-term volunteer enthusiasm is sufficient to explain my observation. Only by entering the actual work of the $\mathrm{W}$ team of Company $\mathrm{C}$ can we gain insight into the hidden core of labor control and ideological control in this new industry.

\section{Manufacturing consent in entertainment labor}

The production of variety shows is a kind of entertainment labor whose specialty is that its form, content, and products are "entertainment". In industrial labor, workers manufacture industrial products by operating machine tools and cooperating with assembly lines to meet the material needs of the people. In entertainment labor, workers produce variety shows, funny videos, and other cultural products by providing jokes, performances, games, and other ideas to meet the audience's sensory entertainment and spiritual and cultural needs. Specifically, when writing script lines, everyone must think about stories and jokes through brainstorming; when recording on-site, they must strive to collect all kinds of jokes as program materials; finally, they must enhance the audiovisual impact of the program through video editing. In short, laborers produce entertainment with amusement and strive to provide entertainment to the audience by amusing themselves.

When answering why, with only a limited marginal income, a worker still desperately overworks, Burawoy clearly stated that domination in the labor process is not only dependent on the political apparatus of production (a series of formal rules and regulations) but also relies on the ideological apparatus of production (Burawoy 1985: 7-8). He found that managers organized work into a "game" to persuade workers to be actively involved. In Director W's team of Company C, the management makes the labor experience "entertainment".

Fundamentally, "entertainment" is like a "game". It is nothing but the "material ritual" described by Althusser to fuse labor control and ideological domination. In the delaborization of labor, it functions as the "automatic machine" that makes it difficult for workers to escape (Han 2017: 100-101). However, from the perspective of concocting tricks, the two are not the same: a "game" focuses on competition-setting rules through institutional tricks, while "entertainment" focuses on experience pleasing the senses through cultural strategies. So how is entertainment labor possible? How can management entertain workers while achieving labor control? From the case of the W team of Company $\mathrm{C}$, we find that three cultural strategies, distinctive in the analysis but inseparable in practice, have played significant roles: relational work, emotional work, and

\footnotetext{
${ }^{3}$ College students also need to consider academic pressure and personal life when choosing an internship. Currently, many enterprises in Shanghai require a part-time internship for more than half a year, and a fulltime internship is much shorter. W team members' full-time internship in the past was basically limited to one to two months during the vacation period.
} 
sentimental work. ${ }^{4}$ In the following, we will analyze the operation of these three strategies in the labor process and then analyze the logic of ideological domination behind "entertainment".

\section{Prelude: relational work and pleasure experience}

People work with colleagues, labor with coworkers, and have fun with friends. Shaping an appropriate relationship is the prerequisite and necessary condition for effective labor. The formal staff of the $\mathrm{W}$ team knows that people can only devote themselves to "entertainment" and enjoy happiness naturally in a comfortable "relationship". Therefore, building an intimate relationship is the first step for them to guide interns to "amuse themselves to death". When interns join the team, their expectation, enthusiasm, and confusion make "relationship" construction more effective.

Vivian A. Zelizer argues that network structure and institutional regulations alone are not enough to form "relationships"; "relationships" are "made". She refers to people's behavior in establishing and maintaining a particular "relationship" as "relational work". Through frequent interactions, people create "relational packages"; that is, they identify relationships, give relationships unique names and negotiated meanings, delineate the boundaries of relationships, choose appropriate exchange media, and shape a variety of "economically beneficial" social relations (Zelizer 2012: 6). Formal employees of the $\mathrm{W}$ team have not read Zelizer but make their actions good footnotes for "relational work". They create intimate relationships with interns through compliments, care, help, and gifts.

As soon as the interns enter the team, they are assigned to different formal employees who are responsible for managing them and are respected by them as "teachers". At this point, relational work begins. Qianqian ${ }^{5}$ from the Department of Journalism at Wuhan University was moved by Ms. W on the first day she entered the team. She says,

I was going to Shanghai alone. Everyone knew each other when I first came to the team, but I didn't even know the teacher's name, and I was very lonely and helpless. In the past few days, Teacher W has been asking me if I have rented an apartment and whether I had sufficient daily necessities. When I asked her if there was a supermarket nearby, unexpectedly, she drove me there and even said that if there was a quilt or something I needed, she would bring it to me from home. I felt so warm! (Interview with Qianqian, an intern, 20161024)

Indeed, "teachers" are the recruiting managers of interns, and their income depends on the profitability of the project; therefore, they are, from the perspective of the nature of their work, no different from foremen or contractors in the construction industry

\footnotetext{
${ }^{4}$ From the perspective of the company, the top executives exercise strict bureaucratic control over formal employees. The most important thing is the KPI assessment system. The income of formal employees is directly linked to the ratings. They are always under pressure from the company's performance evaluation. The director and executive director of the team are rewarded according to the completion of the project. However, there are no specific rules and regulations at the company level to regulate internship labor. All interns are managed by the director's team. Within the director's team, the departmental order is only used to specify the workflow and time point. The specific management and control, heart management, and employment control are conducted through the three cultural strategies described below.

${ }^{5}$ The names appearing in this article are pseudonyms.
} 
and the spinning mills. However, Ms. W is neither like a foreman who oppresses and scolds female workers in spinning mills (Perry 2012), nor like a contractor who takes bullying and commanding posture before construction workers (Pun and Lu 2010), nor like a clientelistic workshop cadre described by Andrew G. Walder (1986). The behavior of "fawning" that appeared in the above studies is from bottom to top: female workers give gifts to foremen, construction workers agree to delayed salary payment, and active members dedicate their loyalty to their leaders. In the $\mathrm{W}$ team, however, the fawning behavior is from top to bottom: "teachers" are intimate friends and life mentors of interns, they are concerned about whether interns quarrel with lovers, and they give them tickets for various entertainment events.

"Look! This is my photo at the Strawberry Music Festival!" Jiajia, who returned from the Strawberry Music Festival, kept telling me that the GALA band live show was much better than the CD. Yoga Lin looked much more handsome than his photo, how sweet Cheer Chen was in real life.... In the past few days, her friends had been bombarded by her Moments on WeChat, a social app. Sometime before, this intern girl from Nanchang University moaned and groaned and was distraught during her work, always muttering, "I want to go to the Strawberry Music Festival." Unexpectedly, Ms. W, who had been an entertainment reporter, gave her a few tickets for reporters and allowed her to take leave for relaxation. During the days of the festival, Jiajia kept paying tribute to Ms. W in her Moments on WeChat. This ecstasy was brought to work in the next few weeks, and Jiajia was very active in brainstorming and devoted very much to the games.

Xiao Jin from Ningbo University had no interest in tween stuff. Her dream lover was Hugh Jackman. On a dull afternoon when Xiao Jin and Ms. $\mathrm{H}$ were editing the video together, she could not help complaining: "I don't want to do editing anymore, I want to go home to watch The Wolverine!" Ms. H said immediately, "Ok, stop editing. I'll take you there." Xiao Jin opened her eyes wide and asked, "What?" Ms. H said, “Tonight, Peter Pan is having its Shanghai Fans and Media Meeting. Hugh Jackman will be there. Do you want to come with me?” Xiao Jin nodded again and again. That night, she sat dreamily in the front row of the meeting, fascinated and staring at her hero all night. She later said, "How was this possible? I didn't expect it! I almost cried!"

The multilayered complex of surprise, freshness, and enthusiasm as a volunteer increases the favorability of the "teachers" to the interns. In a private chat, Xiao Jin said, "The teachers here are different from those of my previous internship in a TV station. Their relationship with you is not the kind that they call you when you have a job and never contact you when you don't have a job. Here, teachers are more like a kind of friendly partner." Compared to school teachers and TV station leaders, "teachers" of the $\mathrm{W}$ team were not only generous, funny, and empathetic but also brought the interns into a colorful and energetic life. As the priestesses of Dionysus, they were friendly, joyful, and charming, singing and dancing. They attracted followers from Thebes to join them in the carnival. Who needs the statues of Pentheus?

Pleasing interns is just a means; the goal is to make them work happily. In her research on "girls" as unpaid laborers in nightclubs, Ashley Mears noted that by giving gifts, providing allowances for food and accommodation, developing love affairs with them and other relational work, brokers turned their labor relationship with "girls" into a relationship of intimacy that made them willing to provide unpaid labor (Mears 2015: 
5). Similarly, relational work in the $W$ team is used for managerial control. For example, as the relationship progressed, Ms. $\mathrm{H}$ began loading Xiao Jin with additional tasks. Once, they went to Macao together to produce a show program. After returning, Ms. $\mathrm{H}$ gave all the editing work to Xiao Jin and said that she would pay her for it. Xiao Jin took the job but refused compensational payment. She said, "I am just doing a favor for my friend. How can I take money to help my friend?" Qianqian, who had bought daily necessities with the help of Ms. W, often helped her with editing work on Sundays: "From a friend's point of view, she has difficulties, and I have time; there is no reason to decline," she said. In addition, "relationships" are used to resolve workplace conflicts. When Jiajia was dissatisfied with not being entrusted as a visual jockey director, Ms. W asked her in a friendly way, "What's wrong with you, Jiajia? Is there something on your mind?" When Jiajia asked for a change of post, Ms. W told her about her difficulties. Jiajia later said, "When someone cares about me, I'm in a much better mood. She told me her difficulties, and I just wanted to stop embarrassing her, and after all, teachers are not easy either." The small sulking mood just disappeared. Friendship loyalty even prevented some interns from going home for the Chinese Lunar New Year. Xiaoping said that she stayed in the company to work overtime during the Spring Festival of 2016 because she thought, "Being trapped in emotions and putting my feet in others' shoes, now it's time for us to help them! We can't leave with a bunch of things behind! It's not righteous. Not kind." In short, intimacy replaces formal systems with interpersonal relationships and market exchanges with social exchanges (Zhu 2016), which facilitates the achievement of managerial control described by Richard C. Edwards (1979: 17).

However, the relationship between relational work and ideology domination is worthy of attention. From the above cases, it can be seen that relational work constitutes the base and prelude of "amusing oneself to death": on the one hand, it is the pleasant experience of being pleased that makes the interns devotedly engage in follow-up labor; on the other hand, intimate relationships make unbridled play and performance possible, and the happy experience more enthusiastic and direct. In the end, relational work quietly changes the nature of specific human activities. Theoretically, the human activity of using the labor force to produce something is to work or "labor" (Marx 2004: 2007), but in practice, when a "teacher" takes an intern to meet a star today or to watch a performance show tomorrow and constantly emphasizes that "we have fun together", the line between labor and entertainment gradually blurs. In this sense, relational work constitutes the first step in the entertainmentization of labor and lays the foundation for the development of entertainment labor.

\section{Melody: emotional work and amusement experience}

After intimacy is established, laborers formally enter the phase of "entertainment". In life, "labor" and "entertainment" are not abstract concepts but real human experiences. The experience of wage labor is unpleasant: "That in his work, therefore he does not affirm himself but denies himself, does not feel content but unhappy” (Marx 1979: 47). The experience of amusement, however, is wonderful because people greatly enjoy beautiful images and exciting music (Postman 2017). How is labor experienced as entertainment? Emotional work plays a key role here. 
The recording of the show itself was an exciting experience: as melodious music echoed on the completely black stage, the soft chasing light shone down with the rain of cherry blossoms, a singer's whisper floated in the darkness, and the interns were moved to tears. When a rocker jumped excitedly, holding his electric guitar while his body trembled uncontrollably, everyone yelled with him. "Beauty offers us pleasure" (Zizek 2002: 276). In entertainment labor, the secretion of a sufficient amount of dopamine caused by the information received via one's eyes, ears, and mouth ignites one's mood. At this time, no one cares how hard it is to carry stage properties around, carry recordings under the feet of guests, and hide in the audience to spark their emotions. However, during the week-long program production, live recording only took one day. During the remaining five working days, the interns needed to spend three days discussing and producing lines of the script, including overnight editing. In this case, the creation of "entertainment" requires the help of a specific emotional atmosphere.

In her analysis of the Chinese Revolution, Elizabeth J. Perry found that party members and cadres flexibly used many methods, such as drama performance, layoutmaking of meeting places, and mass meetings, to create an emotional atmosphere and then evoke the collective emotions conducive to revolutionary work. Perry refers to emotional work as the series of methods used by Communists in various political campaigns to evoke the open expression of anger, fear, and shame (Perry 2001). Emotional work can be used not only to stimulate the revolutionary enthusiasm of peasants but also to stimulate the amusement spirit of interns. In the production of entertainment programs, formal employees used strategies such as performance methods, game methods, and dirty jokes to create an entertaining atmosphere.

In the so-called performance method, the management enables everyone to act as an actor, and an audience member alternately and strategically creates a grotesque stage effect, turning the lines/script discussion into a comedy performance. For example, during a brainstorming session of team $\mathrm{W}$, when the entire team was exhausted and depressed, teacher K, who had always been serious, stood up and said, "Let me do it!" Then, he cleared his throat, holding up the orchid finger, a hand pose of a lady in the Peking Opera; he shook his slightly fattened body of an ordinary middle-aged man and sang the song "Itch" in a fancy and low voice. When he sang the lyric "Come ah, enjoy lah, there is...boundless time yah," many people could not hold back a burst of loud laughter. Drama can arouse the enthusiasm of the audience through the body language of the actors (Hochschild 1983). The intern Xiao Zhi was infected by this artificial but somehow original performance. He excitedly stood up and shouted, "Your performance is not good at all! Let me try. Let me try!" He immediately played the male and female roles in the song "Du Qing". Formal employees were scattered among the interns and helped open their emotional valves in a timely manner to stimulate their emotions through demonstration, guidance, and encouragement.

The game method means that laborers participate together in various boring but happy games. In a discussion, the W team was inspired by an animation called "The Boring World without Dirty Jokes" and designed a game: they tried to get the participant artists to sing a song with tight stockings on their heads, and after singing, the participants competed for taking the stockings off as fast as possible. When explaining the game, Jiajia squinted her eyes into a line, pressed her nose with her fingers to imitate a pig snout, and said, "We do whatever makes us ugly!" When the entertainment 
atmosphere was formed, other people would also be infected. Later, several interns came up with another game: they rode on a reversed swivel chair in the office, holding the back, and jokingly pushed themselves forward with their feet; the farther one went, the better it would be. One intern even took out a hairdryer and sang, "Blow, blow, my pride and indulgence...." While blowing it in the highest gear, the intern's mouth shape and fragmented voice changing with the wind made everyone laugh.

Compared with the discussion of the script, overnight editing is much more boring. At 11 o'clock every Thursday night, interns had to work overnight in the computer room. The secret to make them laugh even when they were completely exhausted physically and mentally was to tell dirty jokes. Dirty jokes make hard work of editing invisible because, first, dirty jokes produce a shared "obscene solidarity" that can subvert symbolic barriers and stimulate the cohesion of the team (Zizek 2002: 4). Mr. H was an expert in warming up the $\mathrm{W}$ team. When the interns were debilitated at midnight, Mr. $\mathrm{H}$ would broach a topic. For instance, to draw everyone's attention, he would yell, "Oh, oh, oh, come and look at this picture!" The interns gave him a supercilious look and said, "Are you too hungry lately?" In a series of gags, everyone's "amusing" enthusiasm was ignited. Second, the overlap of entertainment videos and dirty jokes transformed the work into a "night-time" hilarious "prank" and "high party". Mr. H always created "entertainment events" while editing videos; for example, he dubbed a scene of two men embracing each other with extremely funny sound effects. Everyone heard the sound and rushed over, laughing loudly.

According to Arlie Russell Hochschield, in addition to the body of the laborer, the laborer's emotion is also the object of management by the capital (Hochschild 1983). In entertainment labor, the goal of heart management is to make one remain happy and funny. Here, formal employees use the cultural trick of emotional work to create an atmosphere of amusement through performance methods, game methods, and dirty jokes so that the happy emotions of the laborers naturally emerge, and heart management becomes invisible. Through emotional work, the unrelated, contextless, historyless, and thoughtless situation mentioned by Postman is created (Postman 2017: 94), and it meets the needs of young people for amusement. If relational work blurs the line between entertainment and labor, then emotional work makes entertainment itself a real experience for interns. At this moment, another kind of "amusing oneself to death" appears: "entertainment" uses the senses instead of the brain to force laborers to give up deep thought and indulge in instant emotional gratification, and it makes incoherent self-exploitation attractive. In this sense, entertainment producers are no different from television audiences; both become captives of the representational world.

\section{Climax: sentimental work and sublime experience}

By the time the final six episodes of the program were recorded, the interns had been working nearly $60 \mathrm{~h}$ per week continuously for several months. Even if labor was taken as amusement, it became unbearable. Some people started to lose sleep, some people lost their hair, and many people entered a state of emotional exhaustion (Maslach 1982). In the absence of a labor contract, interns began to consider whether to quit, and the unease gradually spread. At this phase, to keep the interns working, relational 
work and emotional work were insufficient. The W team had to inspire a sense of sacrifice and sublime experience in the interns.

In management research, researchers often advocate promoting corporate culture to improve management efficiency and reduce management costs (Zou and Ding 2007: 164). Many companies claim to have a unique corporate culture and put various slogans on company websites, walls, or even paper cups. However, in the W team, it was not this normative method that stimulated the interns' spirit of sacrifice but the cultural strategy of sentimental work: through speech, inspirational stories, and emotional essays, the management passed their personal purpose to the audience and the interns and stimulated their ethical behavior. The normative system is often superficial, but sentimental work can be integrated deeply into all aspects of work and life. It calls for and praises the corporate culture in an extremely personal way and achieves a direct motivational effect.

"Sacrifice for media ideals" was one of the most important corporate cultural factors of Company C. It originated from the company's founding period. When the start-up team was unstable, Mr. J, the general manager, encouraged crestfallen members who had been working overnight for a long time:

Sometimes I feel that everyone in our Company $\mathrm{C}$ is an angel sent by God and born with a mission. God scattered us all over the country and gathered us together to create this program.

This indescribable "belief" struck everyone instantly. The deputy general manager Mr. D repeated with tears in his eyes,

We have a mission; therefore, we are destined to shoulder more and sacrifice more than ordinary people. We people in Company $\mathrm{C}$ are different. ${ }^{6}$

At that moment, the shocking sense of mission was above all the logic of rational debate and interpretation, and Mr. J's lyrical speech moved everyone into tears. In the end, the start-up team achieved remarkable success after making great self-sacrifices, and despite their various experiences of illnesses such as hyperthyroidism, hemoptysis, and heart disease.

At the team level, storytelling is the most used method in terms of sentimental work. In team building, corporate culture is promoted in an extremely personal way. Ms. W was a big fan of Mr. L., the communications director of Company C. During the first dinner of the entire team, when more than a dozen people were sitting in a hot pot restaurant drinking beer and looking forward to the future, Ms. W told everyone the legend of Mr. L:

Uncle L used to do serious journalism. He was one of the first reporters to arrive at the Wenchuan earthquake site. When the news of the Wenchuan earthquake came, all trains were stopped, but Uncle L took the earliest bus to the stricken area without thinking. Before entering the earthquake area, the road was already

$\overline{{ }^{6} \text { Source: Sniffing Tiger Network }}$ (https://www.huxiu.com/article37571/1.Html) 
broken. At that time, there was no water or electricity. No one was willing to send him in. He walked into the earthquake area step by step by himself... Don't think that doing variety shows is simple. Company bosses are all news-born, but why should our career turn to variety shows? Don't we have journalist ideals anymore? No! It is also ideal for producing the best variety show in China. It is also amazing to enable people to do some high-end things in relaxed entertainment... (Interview with Ms. W, 2015026)

This story of "sacrifice for media ideals" deeply encouraged young people. Jiajia was as excited that evening as if she were told the truth and became enlightened. She later said in an interview,

The seniors turned out to be so amazing! I used to think that entertainment was just to make people laugh, but why can't it be a great career to make people laugh? (Interview with Intern Jiajia, 20161024)

When interns are ready for "sacrifice", management begins to motivate them through lyrical poetry. Oscar Wilde's famous sentence, "We all live in the gutter, but there are still people looking at the stars", is widely quoted in Company C. Mr. T, the vice president, said in a media interview, "We are coal miners, and we suffer so much. But even in the gutter, we have the right to look at the stars." In the last few weeks, Ms. W often used this sentence to motivate exhausted interns. Interns also said in private conversations that no matter how hard it was, they couldn't give up their media ideals. In sacrifice, labor is given a "sublime" experience-a sense of joy that transcends sensory happiness, based on pain and shock, as described by Kant. This experience enables people to obtain "paradoxical pleasure" from suffering and amazing vitality from stagnation (Zizek 2002: 277).

Jiajia once seriously described her feelings:

The bags under my eyes never disappeared! Nevertheless, it mainly depends on how you understand it. I don't think I have an exchange relationship with you for interest, just like ... Once, when the participant artist for whom I was an assistant in the program, lost in the knockout round, I was crying like crazy. I understand that you put in a lot of effort, and so do I. Everyone is more like a comrade in arms fighting for a common cause. (Interview with Intern Jiajia, 20161024)

The sense of sublimity is embedded into the fellowship, which everyone can share. Once, after lengthy editing, when everyone looked up and realized that it was dawn, an intern suddenly asked, "Are we now looking at the sky in the gutter?" Everyone looked at each other and laughed as if by editing videos all night, one became Prometheus.

Finally, the company's annual meeting was a grand ceremony of sentimental expression. Leaders came to the stage and talked about their efforts to overcome difficulties, which made the interns think that all the efforts and sacrifices in the past were worth

$\overline{{ }^{7} \text { Source: Sniffing Tiger Network }}$ (Http://www.huxiu.com/article/37571/1.html) 
it. The climax of the annual meeting was Mr. L's praise for his homeland. One paragraph is as follows:

With music, we, like a mantis trying to stop a chariot, look forward to foretelling the Return... the returning to the place where Chinese music or Chinese culture was first conceived, although weeds have been overgrown here and flowers have not bloomed... I grew up in this country. The people I have contacted since my childhood are the most ordinary in this country. I'm in a career that's most visible to everyone. So, when I have a chance, what more important role is there than to tell [people] about my own country?

That night, three interns decided to continue their internship through "joining the team a 2nd time"; one of them was Xiaojin, who had wanted to quit the team. That night, she forwarded Mr. L's speech to her Moment and wrote excitedly,

Why does this show always give me the feeling that it is not merely an entertainment show? Because the big boss is a person who yearns for poetry and distance. Young men were always fired up like this. (Interview with Intern Xiaojin, 20161008)

Encouraged by enthusiasm and trust, Xiaojin continued her internship at Company C for six months. Jiajia even fell into the gambler's fallacy. Even though Ms. W told her that the company had no vacancy, she remained in the company for 1 year as an intern: "I don't think I have anything else to do except to be a director", she said in the interview.

In general, the importance of sentimental work for labor control lies in the fact that, in the absence of labor contracts and wage incentives, management triggers interns to overcome their physical and mental fatigue and inspires their mental strength by repeating media ideals and praising self-sacrifice. "Thinking does not play well in an image-based culture. There is not much to see in it. It is not a performing art" (Postman 2017: 119). However, sentimental work only requires performing art. The sublime experience generated through sentimental work meets the sentimental needs of the audience and inhibits their critical thinking. Under the shining of divinity, "entertainment" is no longer a vulgar taste without meaning but becomes a spiritual force that spreads happiness and hopes to the world. At this point, the cautionary "amusing to death" has finally sublimated to another level, becoming "sublime entertainment", and it is worth sacrificing. In the end, through reflection on entertainment, entertainment contrarily won a great victory. Who said that the story of Dionysus was just a carnival story? It was originally a story of sacrifice and suffering (Zhang 2008).

In summary, we analyzed the effects of three cultural strategies on manufacturing consent from two aspects: labor control and experience shaping. From the perspective of labor control, through relational work, the management can smoothly carry out administrative control, such as task assignment and dispute coordination; through emotional work, the management can make the interns work happily while keeping the managerial process invisible; and through sentimental work, the management stabilizes internship which is not subjected to labor contracts and makes employment control 
possible. The essential domination is ideological, which is rooted in the entertainment experience of laborers. This experience is shaped in the following ways: first, relational work creates an intimacy based on top-down fawning behavior, making the interns happy; then, emotional work creates a specific emotional atmosphere, allowing the interns to obtain a real experience; and finally, sentimental work allows the interns to gain a sublime experience in self-sacrifice and promotes vulgar entertainment into sublime entertainment. As a result, in the absence of employment contracts, economic incentives, and institutional constraints, laborers continue to have an amazing enthusiasm for laboring. Of course, once the three-month project is completed, the interns will be dismissed, and the $\mathrm{W}$ team will recruit fresh "blood" again when the next project is launched.

It is worth noting that although the above three cultural strategies are different in analysis, they are inseparable in practice. Without relational work, entertainment experience will lose the foundation of "the more, the merrier"; without emotional work, the atmosphere of amusement is water with no source and a tree with no roots; if there is no sentimental work, entertainment itself will disappear in criticism and doubts. From the perspective of specific practices, these three cultural strategies must be mutually supportive. With regard to sequence, relational work is performed first, emotional work is carried out accordingly, and sentimental work is integrated into them promptly. From the perspective of significance, in the early stage of the project, relational work is most important. In the middle of the project, emotional work becomes the core. At the end of the project, sentimental work becomes a pillar. From the perspective of the application, when facing different problems and different individuals, the three are flexibly combined in different ways for efficiency. In short, the three cultural strategies work together from the two aspects of labor control and experience shaping so that the material ritual of "entertainment" can be generated.

\section{From idea to fantasy: new logic of ideological domination}

Sociologists have long regarded ideology as a "false consciousness" that masks social reality. Marx believes that ideology is a basic structure of the historical life of society. It has generated specific values so that human beings cannot see their true relationship with living conditions and are therefore more dependent on existing living conditions (Marx 1961). Althusser inherits and advances this view, arguing that "ideology is indeed a system of representations...they are usually images and occasionally concepts" (Althusser 2006: 229). Burawoy follows this theory and believes that "the labor process is organized into a game, and the goals that the game defines constitute the values currently on the shop floor"; that is, the idea of the shared interests between capital and labor (Burawoy 2008: 228). Later, researchers explored the consent of labor in ideas such as "women should provide more care" (Lively 2000) and "everyone is the boss, and everyone manages" (Zheng et al. 2015).

However, the material practice itself is changing. In today's world, where values are becoming more diverse, whether there is a "concept" of unity and system is itself a question. In the W team, the interns' ideas changed frequently, and everyone had different ideas. Qianqian blatantly mocked her college counselor who reminded her to "beware of being cheated": this counselor questioned why Company $\mathrm{C}$ neither signed 
an internship agreement nor clearly stated internship time. When I asked an intern if she felt she was being exploited, she laughed, saying, "You can't ask me this question as I am a pervert; I like to keep busy". Another intern said, "If you have to work anyway, why don't you work in a more comfortable situation?" No matter how loudly it was claimed that this labor was unfair, the interns did not care. Researchers "must avoid the simple metaphors of demasking, of throwing away the veils which are supposed to hide the naked reality" to understand the role of ideology because the secret of ideology is no longer a secret about the kernel (Zizek2002:39).

Today, the capital discourse has changed from Terry Gou's "Growth, your name is pain" to "You must be happy". The shift suggests that the secret of ideology is no longer the "content" but the "form" itself; it is no longer "an illusion masking the real state of things but that of an (unconscious) fantasy structuring our social reality itself" (Zizek 2002: 28). When Lacan's subversive psychoanalytic thought was introduced into the interpretation of social phenomena, "fantasy" could not be understood as an outlet that provided an escape from reality. On the contrary, it is the reality itself-except that this reality is ideological; it makes people escape traumatic and disorderly kernels and obtain something they desire. It is exactly the logic of Postman's "amusing yourself to death": television provides the audience with a sense of excitement that immerses them and induces them to abandon rational and serious opinions. The same is true of Company C: labor consent is not based on a certain idea but an entertainment fantasy-a "reality" that provides people with instant pleasure (Zizek 2002: 28).

It is in this sense that we put the construction of "experience" at the core of the analysis of labor consent: it is the entertainment experience concocted by cultural strategies such as relational work, emotional work, and sentimental work that created the sublime object of ideology for the interns. They opened their arms to embrace the exciting self-exploitation. "Entertainment" at this time constitutes another material ritual that is different from "games"; it makes high-intensity labor attractive by providing a convincing "fantasy" and an ideological "reality".

\section{Recognizing symptoms and going through the fantasy}

When Burawoy included ideological domination in his analysis of labor control, one of his criticisms was that too much focus was given to the level of consent. It seemed that managerial hegemony was inevitable and easy to survive, but the questioning and resistance of laborers were ignored (Zheng et al. 2015: 175). Gramsci believes that the concept of ideological "hegemony" is a process of hegemonic competition and a dynamic balance. The maintenance of hegemony or "historical result" depends on its response to resistance and dissident actions (Gramsci 2000). Labor control in the W team was not leak-free: of the twenty interns, ten worked until the end of the project, five were fired midway and five actively quit the team (two of them pointed out the labor injustice). Based on this, we will analyze the consciousness and actions of the two dissident interns and their impact on the "entertainment" fantasy in this section.

\section{Symptoms emerge from labor}

"The entire purpose of ideological fantasy is to try to cover up and overcome the cracks in reality in order to create a perfect social existence" (Su 2006: 69). In the production 
process of Company C's variety shows, this crack is the contradiction between entertainment and labor: labor exists in the field of production, and through physical functions, living labor is added to dead labor, and various products are manufactured. Entertainment exists in the field of reproduction, which provides people with a happy experience through sensory stimulation and then relaxes the mind and body. Moreover, in high-intensity labor that lacks institutional incentives, it is difficult for interns to have intrinsic pleasure. Through entertainment mechanisms and ideological fantasy, the two can be stitched together. However, even if the symbolic order stitched by ideological fantasy can maintain dynamic balance, there are still some unfamiliar traumatic factors at its core. They remain the same and cannot be integrated into this order; like privacy, it becomes a "symptom" that the symbolic order is wholly obliterated. ${ }^{8}$ When there are errors in the entertainment mechanism, they appear to destroy the internal consistency of the "fantasy". Although formal employees are careful to hide certain social symptoms, for example, when they want to fire an intern, they often send a WeChat message privately to tell the intern "not to come tomorrow" so that their relationship with the other interns and their friendly image as a "teacher" will not be destroyed. In the following two cases, however, the interns stare at the symptoms.

\section{Accumulation of "symptoms"}

Paradoxical events, if they continue to occur to a laborer, will remind the laborer to notice the disorder of the symbolic order. Xiaoying's example is typical. Successive accidents made her feel that the W team was intolerable.

At the end of the first month of work, Xiaoying had a situation. She suddenly received a phone call from the company's accountant, saying that her allowance could not be paid because her bank card information was incomplete. When Xiaoying insisted that the bank information was not necessary for sending the allowance, the accountant responded, "I'm going to leave work at 4:30 anyway, and you won't receive any money unless you tell!" As a result, Xiaoying did not receive her allowance for that month. This incident hit her hard:

As soon as I thought that I had worked hard for one month, I was really sad. I had no money just because of this problem. I really felt more and more uncomfortable ... I had done so much on my own, and I had to suffer from the accountant! I'll go home, anyway; I've learned what I wanted to learn, and I owe her nothing! (Interview with Intern Xiaoying, 201611107)

However, at this moment, relational work was working. Xiaoying switched her words and said,

\footnotetext{
${ }^{8}$ Symptom and fantasy come from two stages of Lacan's psychoanalytic process: "symptom is a signifying formation which, so to speak, overtakes itself towards its interpretation... fantasy is an inert construction which cannot be analysed, which resists interpretation. Symptom implies and addresses some non-barred, consistent big Other which will retroactively confer on it its meaning; fantasy implies a crossed-out, blocked, barred, non-whole, inconsistent Other - that is to say, it is filling out a void in the Other" (Zizek,2002:103). Symptom causes unpleasant feelings, and fantasy makes us happy. The purpose of ideological critique is to "go through" fantasy, by recognizing symptom.
} 
However, the thought of teachers being so good made me feel sorry for them. (Interview with Intern Xiaoying, 201611107)

The good image of the teachers collapsed in the middle of the project. In the second month, Xiaoying suffered from a urinary tract infection due to overwork, but she was too shy to explain her condition, so she asked Ms. W for a 10-day leave with the excuse that "something happened in school". After understanding the fact, although Ms. W expressed her concern and condolences to Xiaoying verbally, she still deducted 100 yuan per day from Xiaoying's allowance according to the regulations. After first thinking that she had violated the rules, Xiaoying had to admit, "It was my fault ... I couldn't help when the team needed it". Unexpectedly, a few days later, she was in trouble again. The day before recording the show, she was deceived of 3000 yuan by a person who lied about being the cameraman. As a result, Xiaoying not only did not receive her due remuneration but also lost 3000 yuan. Thereafter, she turned her attention to adverse experiences such as long working hours and emotional exhaustion.

During the Spring Festival of 2016, when Ms. W asked Xiaoying to stay and work overtime during the Spring Festival, she left the team angrily. She said in the interview,

Stay up very late very often and work very hard. Those teachers are not friends at all! True friends should consider each other's feelings, but the teachers declined me with all kinds of excuses. And I even have to stay in the company to work overtime during the Spring Festival. What am I doing this for? This little salary is not as much as the red packet gift money given by my parents. (Interview with Intern Xiaoying, 201611107)

In summary, the accumulation of symptomatic events on individual laborers will subvert their entertainment experience, and the gaze at the symptom by laborers will enable them to see the contradictions of the symbolic order. At this time, the laborers begin to question and examine the fantasy.

\section{Authoritative outsider pointing out symptom}

Another challenge to the fantasy of entertainment often comes from authoritative outsiders such as the parents of interns. Although young people always show some resistance to their parents' exhortations, they long for the love of their families and acknowledge their parents' social experience. Therefore, when these people state the contradiction in fantasy, the symptom will be noticed. Xiao Zeng's experience is an example. She had a dispute with her mother before working overtime during the Spring Festival:

Xiao Zeng: I won't go home this Spring Festival. I will stay at the company for extra work.

Mother: You are just an intern, and you don't really want to do this in the future.

And you still have to study. Why do you work so desperately?

Xiao Zeng: My internship is not just for working here! 
Mother: Your salary is so low. I'll directly give you gift money of two thousand yuan for the New Year. Don't do it. Now, go home.

Xiao Zeng: This is not a question of money! We should be responsible.

Mother: You've been tricked into child labor! (Interview with Intern Xiao Zeng, 20710315)

The phrase "tricked into child labor" made her think about whether "entertainment" was her true love or just a job. Later, Xiao Zeng paid attention to the statements and actions of formal employees and found their contradictions:

Yueyue used to have a good relationship with Mr. G, but after Yueyue left Company C, Mr. G talked bad about her in front of us and said words like "as if we are very familiar to each other." Aren't we familiar with each other? Friends can't say bad things about each other in private; is he too quick to fall out? Later, an intern was fired from the team because of me, and I felt guilty. Then I talked to Mr. G about it. I didn't expect him to say, "It doesn't matter, they are all passengers." Am I also a passenger?! (Interview with Intern Xiao Zeng, 20171515)

With the deepening of the gaze, reality changed completely in Xiao Zeng's eyes, which drastically reduced her work motivation; she left the team in March of the following year with the excuse of going to graduate school.

In the above two cases, when laborers encountered incidents that trampled their selfesteem and damaged their entertainment experience, they began to think about their actual situation. Wage deductions, extra work during Chinese New Year, and interpersonal disputes were the "symptoms" that most easily triggered thinking. At this time, a small number of interns find the paradox of entertainment labor due to a traumatic experience and painful feelings; they cannot continue to be happy as they are used as cheap labor.

\section{Symptoms are not contagious}

The quitting of Xiaoying and Xiao Zeng did not cause any waves in the W team partly because the "symptoms" are often verbal and easy to conceal. They only appear by chance. On the other hand, in the absence of open and serious communication, interns tend to individualize others' experiences.

The W team has an unwritten rule that other people's reasons for leaving are not pursued and discussed openly. It is partly due to the reluctance of interns with traumatic experiences to speak out and partly because it is difficult for others to understand their feelings. About the first aspect, Xiao Jin said,

No one deliberately asks why others left. Because even if you ask, they will say that there is something in the school or that their parents are going to be angry. Everyone knows that if you want to continue the internship, neither the school nor your parents are a problem (laughs). (Interview with Intern Xiaojin, 20161008) 
Despite the lack of public discussion, gossip is always present. When we beat around the bush to understand why someone is leaving, the others will personalize the reasons. For example, some people said that Xiaoying left because Ms. W did not like her; some people said that Xiao Zeng felt exploited because she thought herself too much. Regardless of who is gone, others will personalize and particularize the problem and firmly believe that such things will never happen to them. As a result, the interns who noticed the "symptoms" were like barbs on one's finger and were incompatible with the team atmosphere. Their departure eliminated the hidden danger in the team.

It can be said that the stability of ideological domination is based not only on the construction of a perfect social existence but also on the difficulty of challenging the existing symbolic order. Although individual interns can identify the crack in the symbolic order in irregular forms of "symptoms"-a slip of the tongue, mistakes, and incidents-the lack of public discussion and individualized attribution of reasons will transform the common problems faced by interns into specific issues faced by individuals. When unwilling interns leave, they are removed from the team as unstable elements, and the symbolic order is not threatened; instead, the ideological fantasy is consolidated.

\section{Conclusion}

When Postman criticized television culture, saying "in the age of advanced technology... we are a species on the verge of amusing ourselves to death", he did not mention entertainment labor (Postman 2017: 4). We found another way of "amusing ourselves to death" in the labor process of variety entertainment production; that is, the laborer gives up important opinions for the wonderful experience and actively participates in self-exploitation. This "amusing ourselves to death" is a metaphor for the logic of labor control and ideological domination in the current variety entertainment industry.

Today, the only certainty is change. The soil and fertilizer for entertainment labor are different from traditional industries. In the entertainment market, on the one hand, consumer demands are diverse, and user tastes are volatile; on the other hand, the cost of production is relatively low, and fixed asset demand is not large. So entrepreneurs gather in this field. Although the government has provided policy support for industrial development, the market itself is not well regulated. While the news content is strictly censored at the national level, there is a lack of regulation and supervision of business operations. From the perspective of labor inspection, the new industry has received less attention than the traditional industries, which are in the process of transformation and upgrading. Unpaid labor and long-term overtime work exist widely here. This bright and beautiful new industry is being irrigated by competition and risk. The new political and economic soil has given birth to a new logic of manufacturing consent.

In this new logic, the dominant method of labor control is cultural. The case of team $\mathrm{W}$ in Company $\mathrm{C}$ shows a situation in which cultural strategies are used to the extreme: intimacy is used by management to perform task management, job communication, dispute coordination, and other management controls; emotional work is used to create a specific emotional atmosphere and transform heart management into intangibles; sentimental work is used to inspire the heroic spirit and sacrifice of the laborers so that the interns will do their best. When the three aspects of labor control are seamlessly stitched together, the laborers have no reason to reject this shiny golden shackle. 
Of course, when the relationship, atmosphere, and sentiments are greeted with smiles at the front desk, the formal system and market competition are hidden behind the scenes, making the interns feel chilled; if the interns do not work hard to "amuse", they may be removed from the labor market. Parallel to cultural labor control strategies is ideological domination. Entertainment, an experience based on sensory stimulation, is an activity that delights people's ears and eyes, satisfies their emotions, but obscures their ability to think, as described by Postman; it has become a "material ritual" that makes ideological domination possible. The cultural strategies that make labor control possible also shape the real experience of the laborers. The intimate relationship provides a pleasant experience, the entertainment atmosphere triggers a happy and exciting experience, and the great sentiments lead to a sublime experience. The interns' consent to entertainment labor is produced from their immersion in the sublime entertainment experience.

From a theoretical point of view, "entertainment" opens up a new course of analysis of manufacturing consent based on the inheritance of the classic labor process theory. Labor control is transformed from "game" to "entertainment" and from formal institutions to cultural strategy. The ideological domination shifts from idea to experience and from the core to the form. The classical theory holds that the logic of ideological operation in labor is based on false consciousness-it masks, conceals, and even inverts the conditions that enable it to occur so that laborers consent to the social relations in production. However, in the $\mathrm{W}$ team of Company $\mathrm{C}$, the logical of ideological operations behind the creation of consent is a fantasy-a kind of "ideological jouis-sens, enjoyment-in-sense" (Zizek 2002: 62), which instantly ignites the laborers' amusement desire and points out the way to pursue the plus-de-jouir. The management only needs to present all the beautiful things to the laborers, and the laborers actively embrace the happiness and sublimity they expect following the laws of the Big Other. Even if some anomalous, symptomatic factors challenge the symbolic order, it will not vacillate because, in a postmodern context with communication barriers and a high degree of individualization, the questioner will be removed from the system as an "anomaly".

Sadly, the existence of fantasy implies that laborers are ignorant of the nature of their labor. The material world is simply a paradoxical and illusory entity (Zizek 2002: 224), and ideology is nothing but a set of understandings that enables people to face this chaos without falling into despair. When Ms. W told the interns that they could not stay as formal employees after the internship and would work without payment, she did not hide the truth of unpaid labor. The interns were simply more willing to hide themselves in "entertainment" than to accept the cruel reality. Therefore, behind "amusing ourselves to death" is a proactive escape. According to Postman, people have escaped from the field of labor to the field of life. In entertainment labor, people seek to escape during the labor process. In this sense, the helpless and painful yet happy "entertainment" is more tragic than the "game" that promotes victory through competition. 


\section{Funding}

This article is funded by the Youth Project of Shanghai Philosophy and Social Science Program, entitled "Research on the Coordination Mechanism of State-owned Enterprise Labor and Capital Conflicts under Industrial Transformation" (2017ES2004), and the Project of Shanghai Education Commission Chenguang Program, entitled "Research on the Coordination Mechanism of Labor and Capital Conflicts in Factory Regime and State Enterprise" (16CG48).

\section{Availability of data and materials}

We used field work diaries and materials transcribed from unstructured interviews. Readers who are interested in specific sections of the data can contact the corresponding author.

\section{Competing interests}

The authors declare they have no competing interests.

Received: 4 April 2020 Accepted: 8 July 2020

Published online: 09 August 2020

\section{References}

Althusser, L. 1971. Lenin and philosophy and other essays. London: New Left Books.

Althusser, Louis. 2006. Defending Marx, translated by Gu Liang. Beijing: Commercial Press.

Burawoy, M. 1985. The politics of production. Verso Press.

Burawoy, M. 2008. "Manufacturing consent: Changes in the labor process under monopoly capitalism," translated by Li Rongrong. Beijing: Commercial Press.

Chen, H. 2010, "New understanding of the legal status of college students as interns-also on the protection of Interns' Labor Rights and Interests," "Jianghuai Forum" No. 2: pp111-123.

China Radio and Television Yearbook Editorial Department, 2009, China radio and television statistical yearbook 2009, Beijing: China Radio and Television Yearbook. 2015, China radio and television statistical yearbook 2015, Beijing: China Radio and Television Yearbook.

Edwards, R. 1979. Contested terrain: the transformation of the workplace in the twentieth century. New York: Basic Books.

Gallagher, M.E. 2010. "Contagious capitalism: globalization and the politics of labor in China," translated by Yu Jianxing and Xiao Yangdong. Hangzhou: Zhejiang People's Publishing House.

Gramsci, A. 2000. "Prison notebooks," translated by Cao Leiyu. Jiang Li, Zhang Huan, Beijing: China Social Science Press.

Han, Z. 2017. Zizek and Marxism. Beijing: People's Publishing House.

He, M. 2009. "Labor process and the differentiation of sisterhood: a case study on female migrants in China," Social Sciences in China. No. 2: 149-245.

Hochschild, A.R. 1983. The managed heart: The commercialization of human feeling. Los Angeles \& California: University of California Press.

Horkheimer, M., Adorno T. 2006. "Dialectic of enlightenment: Philosophical fragments," translated by Qu Jingdong and Cao Weidong. Shanghai: Shanghai People's Publishing House.

Kücklich, J. 2005, "Precarious playbour: modders and the digital games industry." The Fibreculture Journal. Vol. 25. No. 5. Online article: http://five.fibreculturejournal.org/fci-025-precarious-playbour-moddersand-the-digital-games-industry/

Kunda. G. \& Maanen. J. V. 1999, "Changing scripts at work: managers and professionals." The Annals of the American Academy. Vol.561. pp64-80.

Lee, C. K. 1995, "Engendering the worlds of labor: women workers, labor markets, and production politics in the South China economic miracle." American Sociological Review. Vol. 60. No. 3.pp378-397.

Leidner, R. 1991, "Serving hamburgers and selling insurance: gender, work, and identity in interactive service jobs." Gender and Society. Vol.5. No.2. pp154-177.

Li, P. 2012. A probe into the identification of university students' internship labor relations. Law Science Magazine, Issue 6: $122-125$.

Lively, K. J. 2000, "Reciprocal emotion management: working together to maintain stratification in private law firms." Work and Occupations. Vol.27. No.1.pp32-63.

Mannheim, K. 2000. "Ideology and utopia," translated by Li Ming. Beijing: Commercial Press.

Marx, K. 1961, "The German ideology," translated by Central Compilation and Translation Bureau, Beijing: People's Publishing House.1979, "Economic and philosophical manuscripts of 1844", translated by Liu Kun, Beijing: People's Publishing House. 2004, Volume I of Capital, translated by Central Compilation and Translation Bureau, Beijing: People's Publishing House. 2011, Volume I of Capital, translated by Guo Dali and Wang Yanan, Shanghai: Shanghai Sanlian Bookstore.

Maslach, C. 1982. Burnout: The cost of caring. New York: Prentice-Hall.

Mayer, V. \& Horner, J. 2017, "Student media labor in the digital age: MediaNOLA in the classroom and the university." In Yao, Jinhua(Eds.) Digital Labor in the Media Industry. Beijing: The Commercial Press, pp165-180.

Mears. A. 2015, "Working for free in the VIP: relational work and the production of consent." American Sociological Review. Vol.80. No.6.pp1-24.

Neff, G. Wissinger, E. \& Zukin, S.,2005, "Entrepreneurial labor among cultural producers: 'cool' jobs in 'hot' industries." Social Semiotics. Vol.15, No.3. pp307-334.

Perlin, R. 2011. Intern nation: how to earn nothing and learn little in the brave new economy. London: Verso Press.

Perry, E.J. 2001, "Revisiting the Chinese revolution: an emotional model," China Scholarship, No. 4.pp97-121. 2012, "Shanghai on strike: The politics of Chinese labor," translated by Liu Ping, Nanjing: Jiangsu People's Publishing House.

Peterson. R. A. \& Anand. N, 2002, "How chaotic careers create orderly fields." In M.A. Peiperl. M.B. Arthur. \& N. Anand (Eds.) Career Creativity: Explorations in the Remaking of Work. New York: Oxford University Press, pp257-279.

Postman, N. 2017. "Amusing ourselves to death," translated by Zhang Yan. Beijing: CITIC Publishing House.

Pun, N \& Lu, H. 2010, "A culture of violence: the labor subcontracting system and collective action by construction workers in post-socialist China." China Journal. Vol.64. pp143-158. 
Su, P. 2006. "The secret of ideology: "the shortage of the other" or "the absence of reality"—a preliminary study of Zizek's ideological theory," Philosophical Researches, 8: 66-70.

Thomas, R. J. 1982, "Citizenship and gender in work organization: some considerations for theories of the labor process." American Journal of Sociology. Vol. 88. Pp86-112.

Walder, A.G. 1986. Communist neo-traditionalism: Work and authority in Chinese industry. California: University of California Press.

Zelizer, V. A. 2012, "How I became a relational economic sociologist and what does that mean?". Politics and Society. Vol.40. No. 2. Pp145-174

Zhang, Xian. 2008. The two doors to sacrifice: Dionysus and others. Arts Criticism 8: 65-71.

Zheng, G., Sun, H., Wan, X. 2015. "From 'the game of making out' to 'the game of boss': labor control in the informal employment." Sociological Studies 3: 170-195.

Zhu, Y. 2016. "Social exchange and social relations in workplace: a general theoretical framework of 'embedded' employment relations," Journal of Social Development 4: 84-102.

Zizek, S. 2002. The Sublime object of ideology, Tranlated by Ji Guangmao. Beijing: Central Compilation and Translation Press. Zou, J., Ding, D. 2007, "Basis and principles of corporate culture system construction," Management World 4: 164-165.

\section{Publisher's Note}

Springer Nature remains neutral with regard to jurisdictional claims in published maps and institutional affiliations.

Submit your manuscript to a SpringerOpen ${ }^{\odot}$ journal and benefit from:

- Convenient online submission

- Rigorous peer review

- Open access: articles freely available online

- High visibility within the field

- Retaining the copyright to your article

Submit your next manuscript at $\boldsymbol{\nabla}$ springeropen.com 